ARTICLE

\title{
Mary Seacole and the Virtual Nation
}

\author{
Julia Lee \\ Loyola Marymount University, US \\ juliazenaide@gmail.com
}

Mary Seacole, the so-called "Jamaican Nightingale" and proprietress of the "British Hotel," was valorized for tending to injured British soldiers stationed in the Crimea. This period of her life, described in her travelogue, The Amazing Adventures of Mrs. Seacole, has been the focus of ample critical inquiry. ${ }^{1}$ She was at once a British colonial subject and yet a national icon, a "yellow woman" and yet adoptive "mother" to countless white soldier-sons. Before her career in the Crimea, however, Seacole spent years in another borderlands area, the circum-Caribbean region of Panama. Here, the expansionist threat came not from the Russians but from the Americans, who wished to achieve strategic position in shortening trade routes, especially to the East. It was here that the British Hotel was first founded and where Seacole first became unofficial cultural ambassador of British values. Her table d'hôte became a kind of virtual Britain, dispensing British comforts to a clientele that was overwhelmingly American. This article argues that it was among the Americans in Panama, rather than among the British in Crimea, that Seacole first developed a sense of British nationhood.

Keywords: Mary Seacole; Crimean War; Panama; Transatlantic studies; nationhood

Seacole's wide peregrinations and multiple identities have made her an intriguing, if slippery, subject for critics-both then and now. Sarah Salih (2005) has described the "threefold lack of fit between Seacole's selfidentifications, her contemporaries' categorizations of her, and modern attempts to slot her into a national or racial canon."2 Is Seacole British or American? Caribbean or African-American? Black or "yellow"? Seacole seems to court and even encourage these multiple identities, even as she moves towards what C. L. Innes (2002) calls "a dominant self-representation as a practical woman whose chief satisfaction lies in putting her considerable skills to the services of the British armed forces." ${ }^{3}$ Seacole's time in Panama becomes more than a diverting prelude to the main action in the Crimea. It is a constitutive space in her self-fashioning, a region at the interstices of race and nation. In this "transatlantic imaginary," ${ }^{\prime 4}$ to use Paul Giles's term, Seacole can experiment with multiple identities, mirroring the fluidity of the Atlantic world in which she travelled. Panama becomes a "virtual" space-globalized, decentralized, estranged-where Seacole can challenge rigid markers of identity. ${ }^{5}$

Gillian Whitlock (2000) and Sean Goudie (2008) have begun exploring the Panamanian context to Seacole's narrative. Whitlock sees it as a prologue to Seacole's Crimean adventures, the originating point of

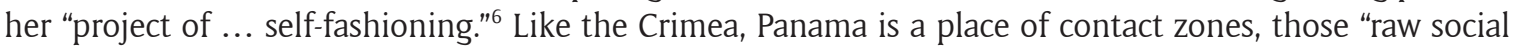

\footnotetext{
${ }^{1}$ See Sandra Gunning, “Traveling with Her Mother's Tastes: The Negotiation of Gender, Race, and Location in “Wonderful Adventures of Mrs. Seacole in Many Lands."' Signs, vol. 26, no.4, pp. 949-981, Sandra Pouchet Paquet, "The Enigma of Arrival: The Wonderful Adventures of Mrs. Seacole in Many Lands." African American Review, vo. 26, no. 4, 1992, pp. 651-663, and Sarah Salih, "'A gallant heart to the empire.' Autoethnography and Imperial Identity in Mary Seacole's Wonderful Adventures," Philosophical Quarterly 83.2 (Spring 2004): 171-195, among others.

2 Sarah Salih, Introduction to The Wonderful Adventures of Mary Seacole in Many Lands. (New York: Penguin, 2005) xvii.

${ }^{3}$ C. L. Innes, A History of Black and Asian Writing in Britain, 1700-2000 (Cambridge: Cambridge UP, 2002) 127.

${ }^{4}$ See Paul Giles, Virtual Americas: Transnational Fictions and the Transatlantic Imaginary (Durham: Duke University Press, 2002).

${ }^{5}$ See Paul Giles, "Virtual Americas: the Internationalization of American Studies and the Ideology of Exchange," American Quarterly 50.3 (Sep., 1998) 523-547.

${ }^{6}$ Gillian Whitlock, The Intimate Empire (London: Cassell, 2000) 91.
} 
spaces where chaos and disorder prevail, where boundaries and appropriate behaviour are not in place." ${ }^{7}$ Goudie looks more particularly at American-Caribbean relations, detaching his analysis from the more famous Crimean episode. Seacole is the Caribbean woman of color who, through her famed hotel, casts herself as a foil to the predatory Yankees. She represents a "civilizing, stabilizing influence in Panama," in resistance to "the hierarchical race, ethnic, class, and gender notions" of her American guests. ${ }^{8}$ Building on Whitlock and Goudie's arguments, I consider New Granada an unofficial American colony where the forces of British and American imperialism clash. It is in this liminal space, far from both the British and American metropoles, that Seacole builds her own virtual nation. The hotel becomes an unofficial British imperial outpost in an unofficial American imperial hinterland. In this contested place, Seacole is not only able to transform from British colonial subject to British imperial representative, but from virtual American to actual Briton.

Following the Spanish-American wars of independence, Panama became a contested space of AngloAmerican imperialist fantasies. The isthmus, which Seacole describes as "a little neck of land, insignificantlooking enough on the map, ${ }^{\prime \prime}$ offered the quickest transit artery between the Atlantic and the Pacific coasts. As early as 1739, the British had considered wresting Panama from Spanish control, and their failure to do so was, according to historian J. C. M. Ogelsby, a missed opportunity "to seize and hold the most important strategic position in the Americas. ${ }^{10}$ In the mid-nineteenth century, the British were the first to dispatch mail steamers to the coast of South America, extending a commercial line through Panama via mule-andcanoe line. That same year, however, the United States acquired Upper California and the Oregon territory (itself a region of Anglo-American conflict) and urgently required a communication line to the region. Sailing around Cape Horn took far too long, and the transcontinental railroad was still decades away from being built. The United States negotiated a treaty with the Republic of New Granada (which controlled the Isthmus) for the right of free and uninterrupted transit between the coasts. In exchange, the United States recognized New Granada (and the Columbia Confederation)'s sovereignty over the Isthmus.

American control of the region was further consolidated with the discovery of gold in 1848 . Hordes of prospectors flooded Panama, eager to reach the gold fields of California. Travel was arduous, dangerous, and primitive, and plans for a railway across the Isthmus were soon launched by the American businessman William $\mathrm{H}$. Aspinwall. In a report to Congress, a Panama railway was couched as critical to American incursion against an entrenched Britannia: "[Great Britain] not only has the ports of the continent of Europe as her neighbors, but she is fifteen hundred miles, or two weeks, nearer than we are to all the other ports of the world, except the Atlantic ports of the American continent north of the equator and the West Indies."11 Without the Panama railroad, the report suggests, the United States would never get out from under Britain's superior geographic-and hence commercial-position. A route through the Isthmus would undercut British hegemony, contracting the distance between American and foreign ports and definitively shifting the locus of power from Europe to the Americas. A "new route across the Isthmus will bring us more than an average of ten thousand miles nearer to the East Indies, China, and the ports of South America on the Pacific, and will actually, for all the purposes of navigation and commercial intercourse, bring the ports of the west coast of Mexico, California, and Oregon, fourteen thousand miles nearer to us than they now are!" the report exclaims. ${ }^{12}$

Panama offered a gateway to the whole world. And like a mythical portal, it drew fortune-seekers into an alternate universe or underworld. Laborers from "from the West Indies, Spanish Main, United States, Europe, and Asia" ${ }^{13}$ converged on the state, seduced by ample work at high wages. Once there, however, they were besieged by heat, humidity, disease, and insects, and many succumbed to the harsh conditions. The Chinese coolies "were attacked by chronic melancholy" ${ }^{14}$ and "fell victims, almost everyone, to a mania for suicide." 15

\footnotetext{
${ }^{7}$ Ibid. 92.

${ }^{8}$ Sean X. Goudie, "Toward a Definition of Caribbean American Regionalism: Contesting Anglo-America's Caribbean Designs in Mary Seacole and Sui Sin Far," American Literature 80.2 (June 2008) 298.

${ }^{9}$ Mary Seacole, Wonderful Adventures of Mrs. Seacole in Many Lands (New York: Penguin, 2005) 17-18.

${ }^{10}$ J. C. M. Ogelsby, "The British and Panama: 1742," Caribbean Studies, 3.2 (July 1963) 78-79.

11 "Report No. 26 of House of Representatives: Railroad across the Isthmus of Panama." January 16, 1849. Thirtieth Congress: Second Session.

${ }^{12}$ Ibid.

${ }_{13}$ Tracy Robinson, Panama: a Personal Record of Forty-Six Years: 1861-1907. New York: the Star and Herald Company, 1907, 15.

${ }^{14}$ John Haskell Kemble, The Panama Route: 1848-1869 (Berkeley and Los Angeles: University of California Press, 1943) 193. For more on the Panama Railway, see Chapter XIV ("The Panama Railroad") in Ira E. Bennett, The History of the Panama Canal (New York: Historical Publishing Company, 1915).

${ }^{15}$ Robinson 15.
} 
The white laborers "withered as cut plants in the sun." ${ }^{16}$ "The "colored contingent," who weathered the conditions better than the others, were "hard to secure in sufficient numbers to carry on the work with the rapidity so ardently desired." 17 Seacole writes that "Every mile of that fatal railway cost the world thousands of lives," ${ }^{18}$ couching railway construction as a sacrifice of global proportions, a war of human ingenuity over a primeval swamp.

Overseeing this multinational crew were American railway officials, forming what one contemporary historian called "a Colony of the Rail." ${ }^{19}$ Despite the heterogeneous origins of its laborers, the "Colony of the Rail" was transparently and culturally an American enterprise. As early as the spring of 1848, the New York Herald quoted a traveler who wrote, "Panama is thoroughly Americanized; has stores for the sale of meats, groceries, bread \&c." ${ }^{20}$ A few years later, another traveller described the town of Aspinwall as "thoroughly Yankeeized." ${ }^{21}$ There were American saloons and American hotels clustered in the frontier cities of Gorgona and Cruces. The American Railway Company even renamed the town of Colon "Aspinwall," replacing the name of one conquistador with another. Seacole recounts how New Granadan authorities refused to recognize such a place, returning letters addressed to Aspinwall with the stamp, "No such place known." 22 Panama was all things to all people: New Granadan sovereign state, a modern Babel, a de facto American colony, a dead letter office.

It was also the dumping ground for what Seacole called "the refuse of every nation," 23 a landfill of humanity. Seacole found herself grouped with these national outcasts when she first arrived in Cruces in 1851 to help her half-brother at his table d'hote, the Independent Hotel, a name that itself shirks national affiliation. She feels herself unwelcome and unknown, even by her brother Edward, who shrugs his shoulders and shakes his head when she cries, "What am I to do? Why did you ever bring me to this place? See what a state I am in-cold, hungry, and wretched." ${ }^{24}$ Familial ties fail; Edward can only clear a corner of the crowded bar and leave Mary "to watch the strange life" around her. From this marginalized space, she wishes herself "safe back in [her] pleasant home in Kingston." ${ }^{25}$ Panama offers no sense of belonging for Seacole, only heightening her sense of estrangement and her conviction that her true "home" is in colonial Jamaica.

Seacole's conception of home or origin begins to evolve, however, in the symbolic, virtual landscape of Panama. What Seacole had earlier described as a "little neck of land" is more like a geologic umbilical cord. According to William Lindsay Scruggs, U.S. minister to Columbia, the natives believed the region to be the "navel of the world," a "source of fabulous wealth" that had been "especially coveted by all nations of the world." ${ }^{26}$ The isthmus divided the hemispheres twice-separating the Atlantic and Pacific oceans and the North and South American continents. In Columbian mythology, Panama was the center, the omphalos, the point of origin. For Mary Seacole, it becomes her own mythical omphalos, a place where she is reborn as British. Here, in the world's navel, surrounded by laborers from every corner of the world, Seacole can create her own national identity by creating her own virtual nation, one with borders, rules, and laws that counteract the lawlessness and chaos of the actual New Granadan state. In Panama, Seacole becomes her own conquistadore, carving out a virtual British colony in a virtual American territory.

Seacole's first act of conquest is an act of naming. "Right opposite my brother's Independent Hotel," she writes, she establishes her "British hotel." ${ }^{27}$ It is an act of competition and affiliation, the first step in her transformation from "the yellow woman from Jamaica with the cholera medicine" ${ }^{28}$ to Mother Seacole, avatar of Mother England. Her customers, it should be remembered, were almost entirely American, and Seacole was, in effect, enabling American expansionist interests. Yet Seacole makes clear that she is no American sympathizer, decrying American barbarism and praising British civility. Even as the Americans import their race prejudice to Panama, bullying native boatmen and muleteers, Seacole notes that the English, outnumbered

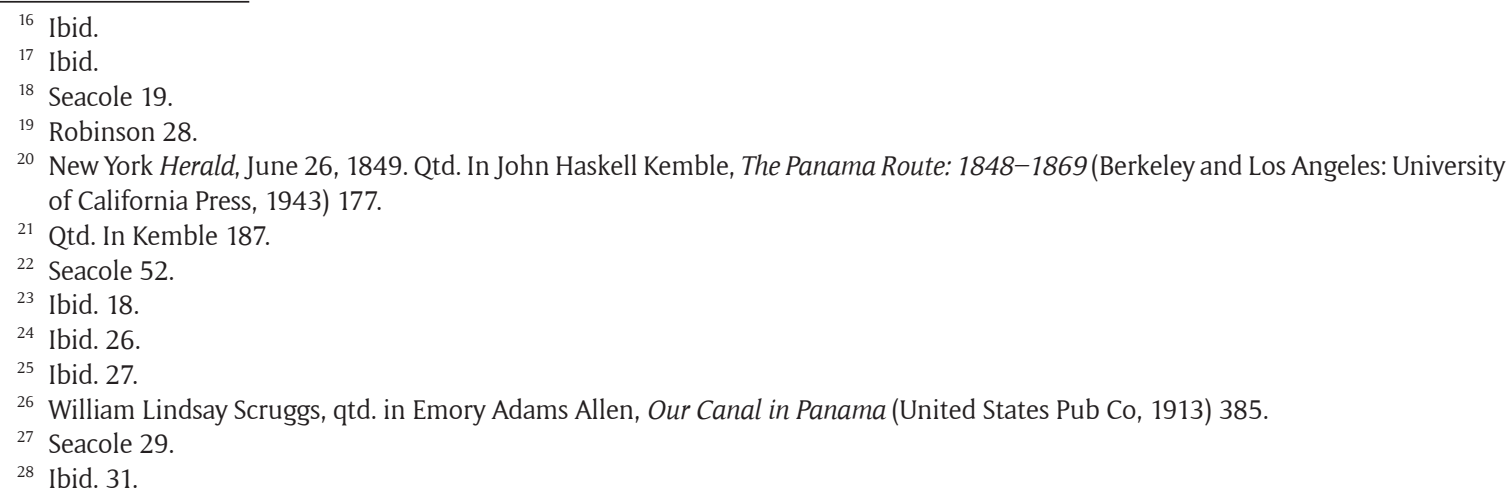


as they are, make their presence felt, "check[ing]" the bullying when they can. ${ }^{29}$ Seacole enacts her own form of cultural diplomacy, importing civilization, cleanliness, and comfort to the Americans-values she portrays as particularly British. She hires a black barber and boasts of "the pleasure and comfort an American feels in a clean chin": "I believe my barber attracted considerable custom [patronage] to the British Hotel at Cruces. ${ }^{130}$ In the absence of an official British presence, Seacole becomes the unofficial cultural ambassador of British values, her hotel one of the few visible markers of a British cultural presence.

Seacole finds herself in a parallel plight to that of Panama, her host country-she welcomes (and profits from) American customers but must simultaneously protect her table d'hote from their incursions. Unlike the New Granadans, however, she is quite a bit more successful. She establishes, in microcosm, a virtual British colony that staves off the expansionist creep of American manifest destiny. Early on, she sets "rules" against American guests, who would invade her space and exploit her hospitality-enacting, on a domestic level, the invasion of Panama. While she acknowledges that the company at her hotel was "not over select" and that "it was often very difficult for an unprotected female to manage them," Seacole learns to hold her ground and to enforce the laws of her establishment. "I had determined that [the British Hotel] should be simply a table d'hote, and that I would receive no lodgers," she writes. "Once, and once only, I relaxed this rule in favour of two American women, who sent me to sleep by a lengthy quarrel of words ..." ${ }^{31}$ It is a mistake she will not repeat twice. She describes dishonest Americans who would try to cheat on their bills of fare and indulge in the "great national American habit of expectoration," but she takes pride in her ability to outwit the unscrupulous. Her table d'hote is literally a "host's table" (a set menu at a price determined by the host) but it is also a guests' table (a constantly shifting array of customers who test the rules of hospitality). ${ }^{32}$

The porousness of boundaries and the difficulties of containment are echoed in the appearance of what I call Seacole's "dark double"-the plague of cholera. Seacole calls the disease an "unwelcome visitor in Cruces," writing, "Before the passengers for Panama had been many days gone, it was found that they had left one of their number behind them, and that one-the cholera." Personified as an unwanted houseguest, cholera is uncontrollable, devastating, genocidal. The native population "did not hesitate to say that this new and terrible plague had been a fellow-traveler with the Americans from New Orleans or some other of its favoured haunts, ${ }^{\prime 3}$ a hypothesis Seacole does not explicitly confirm but that registers the Americans as a biological, as well as imperial, threat. ${ }^{34}$ Seacole arrives in Panama nearly concurrently with this American plague, but she acts as its antidote, the doctress who is initially ignored and unwelcomed but who helps counteract the effects of a fellow immigrant.

Seacole's ideological role combatting cholera in Panama is in striking contrast to her experience combatting yellow fever in Jamaica. Recalling the tropical diseases that felled British colonial officers, Seacole is clear that her sympathies lie squarely with these "young people in the youth and bloom of life" who are stricken down, not in battle with an enemy that threatened their country, but in vain contest with a climate that refused to adopt them. Indeed, the mother country pays a dear price for the possession of her colonies. ${ }^{35}$

Disease here is a native scourge, part of the Caribbean "climate," one of the costs of British imperialism. It is a price paid disproportionately by the metropole rather than the colony. In the circum-Caribbean space of Panama, however, disease is imported by the Americans and disproportionately fatal to the native population, a reversal that further distinguishes British imperialism from American imperialism: the former exacts sacrifices from the colonial power, the latter from the colonial oppressed.

Ironically, Seacole finds herself yet again in the unlikely position of aiding American expansionist interests, successfully nursing many Americans to health while watching futilely as her native patients "died by scores." ${ }^{36}$ With ill-concealed frustration, Seacole describes how the natives submit to cholera with "slavish

${ }^{32}$ For more on the slippage between "hôte" (host) and "hôte" (guest), see Jacques Derrida, Adieu to Emmanuel Levinas, trans. PascaleAnne Brautl and Michael Naas (Stanford: Stanford UP, 1999). See also Goudie's analysis of Seacole and the ethics of hospitality in "Toward a Definition of Caribbean American Regionalism: Contesting Anglo-America's Caribbean Designs in Mary Seacole and Sui Sin Far."

33 Seacole 29.

${ }^{34}$ For more on the migratory patterns of disease and imperialism, see Maria McGarrity, "Mary Seacole's Wonderful Adventures: An Eastward Economy of Disease," Victorian Institute Journal 34 (2006): 127-144.

${ }^{35}$ Seacole 58.

${ }^{36}$ Ibid. 32. This is echoed by Goudie: "Indeed as the narrative progresses, Seacole becomes increasingly anxious about her own ironic
} 
despair." ${ }^{37}$ Elsewhere, Seacole had expressed solidarity with New Granadan natives and American fugitive slaves in their disdain for American bigotry and unruliness, a transnational, hemispheric, racial coalition of those who have found themselves displaced from or marginalized in their "home" countries. Here, though, her lack of racial solidarity with the natives is predicated on their cowardice against the American bioimperial threat. The natives simply submit, even as Seacole works feverishly to revive them. Their lack of resistance-and her lack of success in curing them-compound her feeling of complicity in the American expansionist enterprise. This is heightened when she compares the scene of native devastation to "fearful scenes on the Crimean peninsula among British men." ${ }^{38}$ The comparison of "slavish" natives felled by American-borne cholera to brave British soldiers felled by war, disease, and privation share more than sheer genocidal horror. They are both scenes that underscore a sense of imperial failure against an encroaching enemy. Seacole may resent the natives and romanticize the British, but her sentiments emerge from a sense of defeat against some amorphous other-whether it be disease, violence, or the encoded threat of the Americans or Russians.

Seacole finds herself claimed by both the Americans and the natives, besieged by well-wishers when she herself is struck by cholera. She writes, "It was difficult to keep out the sympathizing Americans and sorrowing natives who came to inquire after me." ${ }^{39}$ Those boundaries Seacole had so carefully enforced in her British Hotel become porous. Weakened by disease, Seacole becomes an unwilling host, forced to accept visitors not on her own terms but on theirs. Healthy, she had remade herself into a British representative; sick, she is susceptible to outside incursions. Her choice of adjectives-the Americans are "sympathizing," the natives "sorrowing"-is telling. The Americans sympathize with her suffering, having endured their own choleric bouts, but assume recovery and even greater strength in its aftermath. The natives are "sorrowing," assuming tragedy, based on the fates of their peers. Soothed by one group and lamented by another, Seacole finds herself in an unhappy subordinate position, pulled towards different camps, neither of which she desires affiliation with. If she recovers, she is claimed by the Americans as a survivor and honorary citizen; if she dies, she joins countless other natives as the victim of the American bio-imperial threat.

Seacole, of course, recovers. Soon after, her national affiliation is explicitly tested during a Fourth of July celebration at her brother's hotel, a moment where Seacole emphatically rejects American citizenship. "A score of zealous Americans" meet "on the anniversary of the declaration of American independence" from England, a fact that cannot be lost on Seacole, who is a member of a colony still under British rule. ${ }^{40}$ Seacole's brother's "Independent Hotel," with its absence of national affiliation, is the neutral ground for this celebration, which is capped by a series of drunken toasts. A "sallow-looking American, with a pompous and yet rapid delivery" raises a glass to "Aunty Seacole" and thanks her for nursing them through cholera. He deems her "the best yaller woman" God ever made, "from Jamaica, gentleman" and then laments,

Well, gentlemen I expect there are only tu things we're vexed for-; and the first is, that she ain't one of us-, a citizen of the great United States-; and the other thing is, gentlemen-, that Providence made her a yaller woman. I calculate, gentlemen, you're all as vexed as I am that she's not wholly white-, but I du reckon on your rejoicing with me that she's so many shades removed from being entirely black-; and I guess, if we could bleach her by any means we would-, and thus make her as acceptable in any company as she deserves to be ... ${ }^{41}$

The American refers to Seacole's origins in Jamaica and says, "she aint' one of us"-"aint"' American but also "aint'" white. In doing so, he also implies that she "aint"" British-that she is somehow nationally as well as racially ambiguous: not wholly white or wholly black, not wholly American or wholly British, merely "yellow" and "from Jamaica." In the absence of obvious national affiliation, the American offers Seacole honorary, or imaginary, American citizenship-in gratitude for services rendered to the American nation.

Unlike the British military medals she would later receive for her efforts on behalf of her British "sons" in the Crimea, Seacole rejects this virtual honor. She scoffs,

complicity with US corporate expansionism in Panama through the healing treatments and surrogate domestic sphere she provides" (303).

37 Ibid. 31.

${ }^{38}$ Ibid. 32

${ }^{39}$ Ibid. 38 .

${ }^{40}$ Ibid. 48

41 Ibid. 48-9. 
I must say, that I don't altogether appreciate your friend's kind wishes with respect to my complexion. If it had been as dark as any nigger's, I should have been just as happy and as useful, and as much respected by those whose respect I value; and as to his offer of bleaching me, I should, even if it were practicable, decline it without any thanks. As to the society which the process might gain me admission into, all I can say is that, judging from the specimens I have met with here and elsewhere, I don't think that I shall lose much by being excluded from it. So, gentlemen, I drink to you and the general reformation of American manners. ${ }^{42}$

In rejecting whiteness, Seacole simultaneously rejects American-ness and its fetishism of race. It is a symbolic gesture, made against the symbolic landscape of Panama, but it simultaneously acts as a moment of self-actualization. Mary Seacole, proprietress of the British Hotel, becomes symbolically British by refusing to become-even symbolically-American. Her toast-"I drink to you and the general reformation of American manners"-is also an oath of allegiance to the British nation. Mary Seacole "ain't one of us"; she is one of "them"-not white, not American, but colored, and British.

Seacole devotes six chapters of her travelogue to her time in Panama, a considerable portion given that her fame coalesced around her time in Crimea (which gets twelve chapters). She closes the Panama section of her adventures with a reflection on her time there and also an update of the region's political situation. Her antipathy for American expansionism could not be more clear. "Recent news from America bring the intelligence that the Government of the United States has at length succeeded in finding a reasonable excuse for exercising a protectorate over, or in other words annexing, the Isthmus of Panama," she writes. "To any one at all acquainted with American policy in Central America, this intelligence can give no surprise; our only wonder being that some such excuse was not made years ago." American expansion in Panama is troubling because it is covert, far different from Russian expansion in the Crimea, which is, at least, explicit. America, in other words, is a kind of invisible enemy. Moreover, American expansionism had nearly claimed Seacole as one of its conquests. Seacole nursed Americans, fed Americans, cut their hair and shaved their beards, endured their abuse and staved off their offers of citizenship and praise. Yet it is the experience in Panama that helps Seacole become British-and allows her to escape before she, too, is annexed. It is by becoming a virtual American that Seacole becomes a real Briton.

\section{Competing Interests}

The author has no competing interests to declare.

\section{References}

Allen, Emory Adams. 1913. Our Canal in Panama. United States Pub Co.

Bennett, Ira E. 1915. The History of the Panama Canal. New York: Historical Publishing Company.

Derrida, Jacques. 1999. Adieu to Emmanuel Levinas, trans. Pascale-Anne Brautl and Michael Naas. Stanford: Stanford UP.

Giles, Paul. 1998. "Virtual Americas: the Internationalization of American Studies and the Ideology of Exchange." American Quarterly, 50(3). Sep., 1998. DOI: https://doi.org/10.1353/aq.1998.0031

Giles, Paul. 2002. Virtual Americas: Transnational Fictions and the Transatlantic Imaginary. Durham: Duke University Press. DOI: https://doi.org/10.1215/9780822384045

Goudie, Sean X. 2008. “Toward a Definition of Caribbean American Regionalism: Contesting Anglo-America's Caribbean Designs in Mary Seacole and Sui Sin Far." American Literature, 80(2). June 2008. DOI: https:// doi.org/10.1215/00029831-2008-004

Gunning, Sandra. 2001. "Traveling with Her Mother's Tastes: The Negotiation of Gender, Race, and Location in 'Wonderful Adventures of Mrs. Seacole in Many Lands."' Signs, 26(4): 949-981. Summer. DOI: https:// doi.org/10.1086/495644

Innes, C. L. 2002. A History of Black and Asian Writing in Britain, 1700-2000. Cambridge: Cambridge UP.

Kemble, John Haskell. 1943. The Panama Route: 1848-1869. Berkeley and Los Angeles: University of California Press.

McGarrity, Maria. 2006. "Mary Seacole's Wonderful Adventures: An Eastward Economy of Disease." Victorian Institute Journal, 34: 127-144.

Ogelsby, J. C. M. 1963. “The British and Panama: 1742." Caribbean Studies, 3(2). July 1963.

\footnotetext{
42 Ibid. 49.
} 
Paquet, Sandra Pouchet. 1992. "The Enigma of Arrival: The Wonderful Adventures of Mrs. Seacole in Many Lands." African American Review, 26(4): 651-663. Winter. DOI: https://doi.org/10.2307/3041877

Robinson, Tracy. 1907. Panama: a Personal Record of Forty-Six Years: 1861-1907. New York: the Star and Herald Company.

Salih, Sarah. 2004. "'A gallant heart to the empire.' Autoethnography and Imperial Identity in Mary Seacole's Wonderful Adventures." Philosophical Quarterly, 83(2): 171-195. Spring.

Seacole, Mary. 2005. Wonderful Adventures of Mrs. Seacole in Many Lands. New York: Penguin.

Whitlock, Gillian. 2000. The Intimate Empire. London: Cassell.

How to cite this article: Lee, Julia. 2019. Mary Seacole and the Virtual Nation. Anthurium, 15(1): 3, 1-7.

Published: 12 February 2019

Copyright: $\odot 2019$ The Author(s). This is an open-access article distributed under the terms of the Creative Commons Attribution 4.0 International License (CC-BY 4.0), which permits unrestricted use, distribution, and reproduction in any medium, provided the original author and source are credited. See http://creativecommons.org/licenses/by/4.0/. 